\title{
Role of extra cellular proteins in gastric cancer progression and metastasis: an update
}

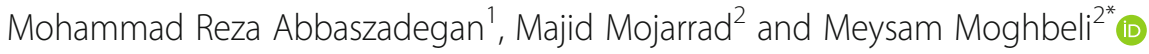

\begin{abstract}
Background: Gastric cancer (GC) is one of the most common cancers in the world with a high ratio of mortality. Regarding the late diagnosis, there is a high ratio of distant metastasis among GC cases. Despite the recent progresses in therapeutic modalities, there is not still an efficient therapeutic method to increase survival rate of metastatic GC cases.

Main body: Apart from the various intracellular signaling pathways which are involved in tumor cell migration and metastasis, the local microenvironment is also a critical regulator of tumor cell migration. Indeed, the intracellular signaling pathways also exert their final metastatic roles through regulation of extra cellular matrix (ECM). Therefore, it is required to assess the role of extra cellular components in biology of GC.

Conclusion: In the present review, we summarize 48 of the significant ECM components including 17 ECM modifying enzymes, seven extracellular angiogenic factors, 13 cell adhesion and cytoskeletal organizers, seven matricellular proteins and growth factors, and four proteoglycans and extra cellular glycoproteins. This review paves the way of determination of a specific extra cellular diagnostic and prognostic panel marker for the GC patients.
\end{abstract}

Keywords: Gastric Cancer, Extra cellular matrix, Metastasis, Microenvironment

\section{Background}

The local microenvironment has critical role in regulation of cell functions [1]. The extracellular matrix (ECM) as noncellular component of microenvironment has important roles in tissue dynamic, morphology, and functions [2]. Therefore, ECM aberration can be associated with abnormal behaviors of cells and tissue homeostasis which results in various disorders such as fibrosis and cancer $[3,4]$. The proteins, proteoglycans, polysaccharides, and minerals are some of the main components of ECM that shape basement membrane and interstitial matrix [5]. ECM is composed of various proteins such as collagens, laminins, proteoglycans, and remodeling enzymes. Beside the structural roles, the

\footnotetext{
*Correspondence: Meysam_moghbeli@yahoo.com; moghbelim@mums.ac.ir ${ }^{2}$ Department of Medical Genetics and Molecular Medicine, School of Medicine, Mashhad University of Medical Sciences, Mashhad, Iran Full list of author information is available at the end of the article
}

ECM is associated with signaling pathways and growth factors through binding with BMPs, FGFs, hedgehogs, and WNTs [2]. Therefore, aberrant ECM composition can be oncogenic. ECM degrading enzymes including metalloproteinase and serine protease have destructive influences on tissues which highlights the regulatory role of ECM remodeling enzymes during transcriptional, translational, and posttranslational levels $[6,7]$. Type I collagen is the most common type in interstitial matrices, whereas type IV collagen is essential in basement membrane [8]. Collagens function as a scaffold to facilitate tumor cell migration [9]. Increased collagens deposition have been reported during tumor formation [10]. Aging decrease and increase collagen deposition and MMP activity, respectively. Abnormal ECM dynamics promote epithelial mesenchymal transition (EMT) via basement membrane disruption using MMPs up regulation which is a critical 
step during tumor progression $[11,12]$. Since the EMT results in cancer stem cell like properties and drug resistance, it facilitates tumor metastasis [13, 14]. Tumor angiogenesis is also another process associated with ECM in which many ECM components such as endostatin, arresten, and hexastatin have inducing or inhibitory angiogenic functions [15]. The G1/S cell cycle progression is also associated with ECM-cell adhesion in which the ECM activate growth factor through ERK signaling $[16,17]$. Moreover, the immune cell processes such as infiltration and activation can be affected by ECM [18].

Carcinogens exert their impact through DNA damage, aberrant cellular processes, and microenvironment alteration [19]. The effects of majority of carcinogens are occurred through modulation of tumor microenvironment. Tumorigenesis is associated with activation of various cell types such as stem cells, fibroblasts, and hematopoietic cells which recruit immune cells to produce cytokines [20,21]. Carcinogens can change the functions of these cells and ECM components [22]. Tissue remodeling is known by changes in expression and degradation of ECMs [23]. Matrix metalloproteinases (MMPs) as the main ECM remodelers can be affected by carcinogens. Chronic exposure to heavy metals, nicotine, and radiation are associated with tissue remodeling [24, 25]. Moreover, some chemicals regulate tissue remodeling through up regulation of growth factors, cytokines, and extracellular proteins in host cells. These alterations in tissue remodeling genes results in tissue architecture changes which promotes tumor progression [26].

Gastric Cancer (GC) is the fourth common and the second leading cause of cancer-related deaths in the world [27]. Distant metastases are observed among a noticeable ratio of GC patients at the time of diagnosis which have not an effective treatment (5-year survival rate is up to 10\%) [28-30]. Therefore, introduction of circulating biomarkers can be helpful to improve early detection and prognosis in such patients. Increased protein-specific fragments belonged to the ECM turnover are released into blood following an aberrant ECM remodeling which can be used as circulating biomarkers for diagnostic and prognostic purposes in cancer patients [31]. Since the main reason of distant metastasis is local microenvironment and extracellular matrix, in the present review, we summarize 47 of the significant ECM proteins which have been reported until now among GC patients in the world including 17 ECM modifying enzymes, seven extracellular angiogenic factors, 12 cell adhesion and cytoskeletal organizers, seven matricellular proteins and growth factors, and four proteoglycans and extra cellular glycoproteins (Table 1). Official symbol, official full name, gene ID, and URL of the reported genes in the present study referred from National Center for Biotechnology Information (https://www.ncbi.nlm.nih. gov) are also presented in Table 2.

\section{Main text \\ ECM modifying enzymes}

In this section, we summarize 17 gene products including seven matrix metallopeptidases (MMP1, MMP2, MMP7, MMP9, MMP14, MMP24 and MMP25), laminin subunit gamma 2 (LAMC2), three ADAMTS metallopeptidases (ADAMTS1, ADAMTS8 and ADAMTS18), 2 TIMP metallopeptidases (TIMP1, TIMP3), three lysyl oxidase (LOX, LOXL4, and PLOD2), and tissue factor pathway inhibitor 2 (TFPI2).

Matrix metalloproteinases (MMPs), heparanase, cathepsins, urokinase plasminogen activator, and lysyl oxidase are ECM modifying enzymes contributing with tumor metastasis [77-79]. Degradation of ECM is mainly mediated by MMPs which are zinc dependent endopeptidases secreted by various cells such as fibroblasts and endothelial cells. Their activation is depended to the calcium and neutral $\mathrm{pH}[80,81]$. MMPs are categorized based on their substrate and cellular location into four groups including collagenases, stromelysins, gelatinases, and membraneassociated MMPs. Regulation of ECM through MMPs has a key role in tumor progression and metastasis [82]. Beside other proteases, the MMPs can also activate variety of factors such as tyrosine-kinase receptors, growth factors, and cell-adhesion molecules [7, 80]. Type IV collagen is one of the main components of basal membranes and ECM which can be degraded via MMP2 and MMP9 [83]. The $1562 \mathrm{C} / \mathrm{T}$ promoter polymorphism of MMP9 has been assessed in a sub population of Japanese GC cases which showed higher frequency of $\mathrm{T}$ allele in advanced-stage $\mathrm{GC}$ cases. Moreover, $\mathrm{T}$ allele significantly increased the lymph node involvement [32]. Another study has been reported that there were correlations between MMP9 expression, stage, depth of tumor invasion, and lymph node involvement which suggested the MMP9 as a marker of GC metastasis [33]. MMP9 had significant increased levels of expression in advanced stage tumors in comparison with early gastric tumors [34]. MMP1 as a collagenase has a critical role in ECM remodeling. It can be regulated by various transcription factors such as AP1, AP2, and retinoic acid [84]. The 1G/2G promoter polymorphism of MMP1 was assessed in GC patients and showed that there was a significant correlation between $2 \mathrm{G}$ allele and poorly differentiation [35]. It has been shown that there was a correlation between rs1799750 and GC in which the patients had significantly higher frequency of $2 \mathrm{G}$ allele compared with controls. Moreover, the 2G/2G carriers significantly had higher risk of tumor invasion in comparison with 1G/ $1 G+1 G / 2 G$ genotype [36]. MMP2 has a key role in primary steps of tumor progression [85]. Cyclo-oxygenase 2 (COX2) is also associated with inflammation and tumorigenesis that up regulates the MMPs through prostanoids [86]. It has been reported that the epithelial MMP2 expression was correlated with COX2 over expression in GC 
Table 1 All of the ECM related factors involved in gastric cancer progression and metastasis

\begin{tabular}{|c|c|c|c|c|c|}
\hline Gene & Results & Country & population & Year & Reference \\
\hline \multicolumn{6}{|l|}{ ECM modifying enzymes } \\
\hline MMP9 & Polymorphism was correlated with invasive phenotype & Japan & $\begin{array}{l}177 \text { patients } \\
224 \text { controls }\end{array}$ & 2005 & Matsumura [32] \\
\hline MMP9 & $\begin{array}{l}\text { MMP9 expression was correlated with stage, depth of } \\
\text { tumor invasion, and lymph node involvement }\end{array}$ & Poland & 54 patients & 2009 & Mroczko [33] \\
\hline MMP9 & increased levels of expression in advanced stage tumors & Serbia & $\begin{array}{l}40 \text { patients } \\
11 \text { controls }\end{array}$ & 2009 & $\begin{array}{l}\text { Dragutinovic } \\
{[34]}\end{array}$ \\
\hline MMP1 & Polymorphism was correlated with poorly differentiation & Japan & $\begin{array}{l}215 \text { patients } \\
166 \text { controls }\end{array}$ & 2004 & Matsumura [35] \\
\hline MMP1 & Polymorphism was correlated with GC risk & China & $\begin{array}{l}422 \text { patients } \\
428 \text { controls }\end{array}$ & 2014 & Dedong [36] \\
\hline MMP2 & $\begin{array}{l}\text { MMP2 expression was correlated with poor survival, stage, } \\
\text { and diffuse type }\end{array}$ & Finland & 315 patients & 2006 & Mrena [37] \\
\hline MMP14 & $\begin{array}{l}\text { High levels of serum MMP14 was correlated with poor } \\
\text { survival }\end{array}$ & Finland & 240 patients & 2018 & Kasurinen [38] \\
\hline MMP7 and LAMC2 & $\begin{array}{l}\text { MMP7 and LAMC2 expressions were correlated with } \\
\text { tumor aggressiveness }\end{array}$ & Japan & 790 patients & 2014 & Sentani [39] \\
\hline $\begin{array}{l}\text { ADAMTS8, ADAMTS18, and } \\
\text { ADAMTS1 }\end{array}$ & Expressions were correlated with stage & Turkey & 25 patients & 2017 & Kilic [40] \\
\hline TIMP1 & $\begin{array}{l}\text { TIMP1 expression was correlated with advanced stages, } \\
\text { increased depth of invasion, and metastatic lymph nodes }\end{array}$ & Poland & 54 patients & 2009 & Mroczko [41] \\
\hline MMP2, MMP24, and MMP25 & MMP2, MMP24, and MMP25 increased expression & Mexico & $\begin{array}{l}17 \text { patients } \\
22 \text { controls }\end{array}$ & 2014 & De la pena [42] \\
\hline LOX & Over expression was correlated with local tumor relapse & China & 184 patients & 2018 & Peng [43] \\
\hline LOXL4 & $\begin{array}{l}\text { Over expression was correlated with tumor size, depth } \\
\text { of invasion, stage, and survival }\end{array}$ & China & 379 patients & 2015 & Li [44] \\
\hline PLOD2 & Expression was correlated with peritoneal metastasis & Japan & 179 patients & 2018 & Kiyozumi [45] \\
\hline TFPI2 & Hyper methylation & China & 114 patients & 2017 & $\mathrm{Hu}[46]$ \\
\hline ETS1 & $\begin{array}{l}\text { over expression induced mucosal into the sub mucosal } \\
\text { tumor invasion }\end{array}$ & Japan & 110 patients & 1996 & Nakayama [47] \\
\hline \multicolumn{6}{|l|}{ Extra cellular angiogenic factors } \\
\hline BSG & $\begin{array}{l}\text { Expression was correlated with tumor size and lymph } \\
\text { node metastasis }\end{array}$ & Japan & $\begin{array}{l}234 \text { tumors } \\
85 \text { normal }\end{array}$ & 2006 & Zheng [48] \\
\hline MMRN2, EMILIN1, and EMILIN2 & $\begin{array}{l}\text { High expression of MMRN2 in normal gastric mucosa } \\
\text { along blood vessels, while the EMILIN2 and EMILIN1 } \\
\text { expressions were limited to the lamina propria. }\end{array}$ & Italy & 51 patients & 2018 & Andreuzzi [49] \\
\hline HPSE & Polymorphism was correlated with survival & China & $\begin{array}{l}155 \text { patients } \\
204 \text { controls }\end{array}$ & 2010 & Yue [50] \\
\hline CTHRC1 & Expression was correlated with depth of invasion & China & 116 patients & 2012 & Wang [51] \\
\hline CTHRC1 & $\begin{array}{l}\text { Expression was associated with tumor stage, } \\
\text { differentiation, survival, and prognosis, depth of invasion, } \\
\text { lymph node involvement, and tumor size. }\end{array}$ & China & $\begin{array}{l}166 \text { tumors } \\
30 \text { normal }\end{array}$ & 2014 & Gu [52] \\
\hline ECM1 & $\begin{array}{l}\text { Expression was correlated with tumor relapse, poor } \\
\text { survival, and advanced stages. }\end{array}$ & China & 241 patients & 2018 & Gan [53] \\
\hline ECM1 & $\begin{array}{l}\text { Expression was correlated with tumor depth of invasion } \\
\text { and stage. }\end{array}$ & China & 77 patients & 2014 & Wu [54] \\
\hline \multicolumn{6}{|l|}{$\begin{array}{l}\text { Cell adhesion and cytoskeletal } \\
\text { organizers }\end{array}$} \\
\hline $\mathrm{PCDH} 8$ & Was correlated with poor prognosis. & China & 144 patients & 2018 & Lin [55] \\
\hline CLDN4 & $\begin{array}{l}\text { Expression was correlated with depth of invasion and } \\
\text { lymph node involvement }\end{array}$ & Taiwan & 189 patients & 2010 & Hwang [56] \\
\hline LLGL1 & Was correlated with distant metastasis. & Germany & 56 patients & 2019 & Desuki [57] \\
\hline
\end{tabular}


Table 1 All of the ECM related factors involved in gastric cancer progression and metastasis (Continued)

\begin{tabular}{|c|c|c|c|c|c|}
\hline Gene & Results & Country & population & Year & Reference \\
\hline FN1 & increased serum levels & Turkey & $\begin{array}{l}63 \text { patients } \\
30 \text { controls }\end{array}$ & 2016 & Tas [58] \\
\hline FNDC1 & Expression was correlated with sex, survival, and stage. & China & 90 patients & 2018 & Ren [59] \\
\hline ANOS1 & Expression was correlated with stage and prognosis. & Japan & 237 patients & 2016 & Kanda [60] \\
\hline ITGA4 & Methylation & Korea & 46 patients & 2004 & Park [61] \\
\hline ICAM1 (CD54) & $\begin{array}{l}\text { Expressions were correlated with stage and lymph node } \\
\text { involvement. }\end{array}$ & China & 84 patients & 2014 & Dong [62] \\
\hline CFL1 & Over expression & China & 33 patients & 2017 & Wang [63] \\
\hline HMMR (CD168) & Inverse correlation with lymph node involvement. & Japan & 196 patients & 2011 & Ishigami [64] \\
\hline MFAP2 & $\begin{array}{l}\text { Expression was correlated with depth of invasion, lymph } \\
\text { node involvement, tumor stage, and poor overall survival }\end{array}$ & China & 168 patients & 2018 & Wang [65] \\
\hline SPON2 & $\begin{array}{l}\text { Expression was correlated with grade of tumor } \\
\text { differentiation, depth of invasion, lymph node } \\
\text { involvement, and advanced stages. }\end{array}$ & China & 174 patients & 2017 & $\operatorname{Jin}[66]$ \\
\hline \multicolumn{6}{|c|}{$\begin{array}{l}\text { Matricellular proteins and } \\
\text { growth factors }\end{array}$} \\
\hline SPARC & Was correlated with serosal invasion and poor survival. & Japan & 227 patients & 2013 & Sato [67] \\
\hline SERPINE1 AND SPARC & Expressions were correlated with poor survival. & China & $\begin{array}{l}293 \text { tumors } \\
196 \text { normal }\end{array}$ & 2018 & Liao [68] \\
\hline SPARCL1 & $\begin{array}{l}\text { Expression was correlated with prognosis, survival, size, } \\
\text { and grade. }\end{array}$ & China & $\begin{array}{l}1072 \\
\text { patients }\end{array}$ & 2012 & Li [69] \\
\hline FGFR2 AND THBS1 & Over expressions & China & 53 patients & 2017 & Huang [70] \\
\hline LTBP2 & $\begin{array}{l}\text { Expression was correlated with depth of invasion, stage, } \\
\text { lymph node involvement, poor survival. }\end{array}$ & China & 174 patients & 2018 & Wang [71] \\
\hline POSTN & Inverse correlation between expression and stage. & China & $\begin{array}{l}25 \text { tumors } \\
8 \text { normal }\end{array}$ & 2014 & LV [72] \\
\hline \multicolumn{6}{|c|}{$\begin{array}{l}\text { Proteoglycans and extra cellular } \\
\text { glycoproteins }\end{array}$} \\
\hline VCAN & Expression was correlated with poor prognosis. & China & 101 patients & 2015 & Shen [73] \\
\hline ASPN & Over expression. & China & 46 patients & 2015 & Ding [74] \\
\hline LUM & $\begin{array}{l}\text { Up regulation in gastric CAFs was correlated with } \\
\text { advanced stage, poor survival, depth of invasion, and } \\
\text { lymph node involvement. }\end{array}$ & China & 117 patients & 2017 & Wang [75] \\
\hline MUC2 & Was correlated with grade. & Egypt & 28 patients & 2011 & Khattab [76] \\
\hline
\end{tabular}

patients. Moreover, there were correlations between stromal MMP2 expression, poor survival, stage, and diffuse type, whereas the MMP9 was associated with intestinal type [37]. MMP14 is belonged to the membrane-bound MMPs. It has been observed that the serum MMP14 was an independent prognostic factor of GC in which the men with high levels of serum MMP14, pT3-4 tumors, and metastatic lymph nodes had poor survival [38]. MMP7 targets various ECM components such as collagens, elastin, and fibronectin. Laminins are associated with cellular adhesion and differentiation [87].

Laminin subunit gamma 2 (LAMC2) is expressed in tumor cells and can be used as a marker of malignant epithelial cells [88]. The LAMC2 has an epidermal growth factor (EGF)-like domain [89] which can be processed by MMP [90] to interrupt the hemidesmosomes via EGFR of b4 integrin during tumor cell migration. It has been shown that the MMP7, LAMC2, and EGFR expressions were correlated with tumor aggressiveness, advanced $\mathrm{T}$ grade, and tumor stage in GC tumors [39].

The human ADAMTS (a disintegrin and metalloproteinase with thrombospondin-like motifs) family of 19 secreted, multidomain proteolytic enzymes is involved in a wide range of biological processes including ECM assembly and degradation, hemostasis, organogenesis and the regulation of angiogenesis [91]. Immunohistochemical assessments have been shown the high expression levels of ADAMTS1, 8, and 18 in GC patients. There were correlations between increased ADAMTS1 and ADAMTS18 expressions and lymph node involvement which introduced them as the markers of lymphatic metastasis in GC patients. The ADAMTS8, ADAMTS18, 
Table 2 ECM related genes studied in GC patients

\begin{tabular}{|c|c|c|c|}
\hline Official symbol & Official full name & Gene ID & URL \\
\hline ADAMTS1 & ADAM metallopeptidase with thrombospondin type 1 motif 1 & 9510 & https://www.ncbi.nlm.nih.gov/gene/9510 \\
\hline ADAMTS18 & ADAM metallopeptidase with thrombospondin type 1 motif 18 & 170,692 & https://www.ncbi.nlm.nih.gov/gene/170692 \\
\hline ADAMTS8 & ADAM metallopeptidase with thrombospondin type 1 motif 8 & 11,095 & https://www.ncbi.nlm.nih.gov/gene/11095 \\
\hline ANOS1 & Anosmin 1 & 3730 & https://www.ncbi.nlm.nih.gov/gene/3730 \\
\hline ASPN & Asporin & 54,829 & https://www.ncbi.nlm.nih.gov/gene/54829 \\
\hline BSG & Basigin (Ok blood group) (EMMPRIN) & 682 & https://www.ncbi.nlm.nih.gov/gene/682 \\
\hline CFL1 & Cofilin 1 & 1072 & https://www.ncbi.nlm.nih.gov/gene/1072 \\
\hline CLDN4 & Claudin 4 & 1364 & https://www.ncbi.nlm.nih.gov/gene/1364 \\
\hline CTHRC1 & Collagen triple helix repeat containing 1 & 115,908 & https://www.ncbi.nlm.nih.gov/gene/115908 \\
\hline CXCR1 & C-X-C motif chemokine receptor 1 & 3577 & https://www.ncbi.nlm.nih.gov/gene/3577 \\
\hline CXCR2 & C-X-C motif chemokine receptor 2 & 3579 & https://www.ncbi.nlm.nih.gov/gene/3579 \\
\hline ECM1 & Extracellular matrix protein 1 & 1893 & https://www.ncbi.nlm.nih.gov/gene/1893 \\
\hline EGFR & Epidermal growth factor receptor & 1956 & https://www.ncbi.nlm.nih.gov/gene/1956 \\
\hline EMILIN1 & Elastin microfibril interfacer 1 & 11,117 & https://www.ncbi.nlm.nih.gov/gene/11117 \\
\hline EMILIN2 & Elastin microfibril interfacer 2 & 84,034 & https://www.ncbi.nlm.nih.gov/gene/84034 \\
\hline ETS1 & ETS proto-oncogene 1, transcription factor & 2113 & https://www.ncbi.nlm.nih.gov/gene/2113 \\
\hline FGF7 & Fibroblast growth factor 7 & 2252 & https://www.ncbi.nlm.nih.gov/gene/2252 \\
\hline FGFR2 & Fibroblast growth factor receptor 2 & 2263 & https://www.ncbi.nlm.nih.gov/gene/2263 \\
\hline FN1 & Fibronectin 1 & 2335 & https://www.ncbi.nlm.nih.gov/gene/2335 \\
\hline FNDC1 & Fibronectin type III domain containing 1 & 84,624 & https://www.ncbi.nlm.nih.gov/gene/84624 \\
\hline FOXC2 & Forkhead box C2 & 2303 & https://www.ncbi.nlm.nih.gov/gene/2303 \\
\hline HMMR & Hyaluronan mediated motility receptor (CD168) & 3161 & https://www.ncbi.nlm.nih.gov/gene/3161 \\
\hline HPSE & Heparanase & 10,855 & https://www.ncbi.nlm.nih.gov/gene/10855 \\
\hline ICAM1 & Intercellular adhesion molecule 1 (CD54) & 3383 & https://www.ncbi.nlm.nih.gov/gene/3383 \\
\hline ITGA4 & Integrin subunit alpha 4 & 3676 & https://www.ncbi.nlm.nih.gov/gene/3676 \\
\hline LAMC2 & Laminin subunit gamma 2 & 3918 & https://www.ncbi.nlm.nih.gov/gene/3918 \\
\hline LGALS1 & Galectin 1 & 3956 & https://www.ncbi.nlm.nih.gov/gene/3956 \\
\hline LLGL1 & LLGL scribble cell polarity complex component 1 & 3996 & https://www.ncbi.nlm.nih.gov/gene/3996 \\
\hline LOX & Lysyl oxidase & 4015 & https://www.ncbi.nlm.nih.gov/gene/4015 \\
\hline LOXL4 & Lysyl oxidase like 4 & 84,171 & https://www.ncbi.nlm.nih.gov/gene/84171 \\
\hline LTBP2 & Latent transforming growth factor beta binding protein 2 & 4053 & https://www.ncbi.nlm.nih.gov/gene/4053 \\
\hline LUM & Lumican & 4060 & https://www.ncbi.nlm.nih.gov/gene/4060 \\
\hline MFAP2 & Microfibril associated protein 2 & 4237 & https://www.ncbi.nlm.nih.gov/gene/4237 \\
\hline MMP1 & Matrix metallopeptidase 1 & 4312 & https://www.ncbi.nlm.nih.gov/gene/4312 \\
\hline MMP14 & Matrix metallopeptidase 14 & 4323 & https://www.ncbi.nlm.nih.gov/gene/4323 \\
\hline MMP2 & Matrix metallopeptidase 2 & 4313 & https://www.ncbi.nlm.nih.gov/gene/4313 \\
\hline MMP24 & Matrix metallopeptidase 24 & 10,893 & https://www.ncbi.nlm.nih.gov/gene/10893 \\
\hline MMP25 & Matrix metallopeptidase 25 & 64,386 & https://www.ncbi.nlm.nih.gov/gene/64386 \\
\hline MMP7 & Matirix metallopeptidase 7 & 4316 & https://www.ncbi.nlm.nih.gov/gene/4316 \\
\hline MMP9 & Matrix metallopeptidase 9 & 4318 & https://www.ncbi.nlm.nih.gov/gene/4318 \\
\hline MMRN2 & Multimerin 2 & 79,812 & https://www.ncbi.nlm.nih.gov/gene/79812 \\
\hline MUC2 & Mucin 2, oligomeric mucus/gel-forming & 4583 & https://www.ncbi.nlm.nih.gov/gene/4583 \\
\hline MUC6 & Mucin 6, oligomeric mucus/gel-forming & 4588 & https://www.ncbi.nlm.nih.gov/gene/4588 \\
\hline NODAL & Nodal growth differentiation factor & 4838 & https://www.ncbi.nlm.nih.gov/gene/4838 \\
\hline
\end{tabular}


Table 2 ECM related genes studied in GC patients (Continued)

\begin{tabular}{|c|c|c|c|}
\hline Official symbol & Official full name & Gene ID & URL \\
\hline PCDH8 & Protocadherin 8 & 5100 & https://www.ncbi.nlm.nih.gov/gene/5100 \\
\hline PLOD2 & Procollagen-lysine,2-oxoglutarate 5-dioxygenase 2 & 5352 & https://www.ncbi.nlm.nih.gov/gene/5352 \\
\hline POSTN & Periostin & 10,631 & https://www.ncbi.nlm.nih.gov/gene/10631 \\
\hline SERPINE1 & Serpin family E member 1 & 5054 & https://www.ncbi.nlm.nih.gov/gene/5054 \\
\hline SPARC & Secreted protein acidic and cysteine rich & 6678 & https://www.ncbi.nlm.nih.gov/gene/6678 \\
\hline SPARCL1 & SPARC like 1 & 8404 & https://www.ncbi.nlm.nih.gov/gene/8404 \\
\hline SPON2 & Spondin 2 & 10,417 & https://www.ncbi.nlm.nih.gov/gene/10417 \\
\hline TFPI2 & Tissue factor pathway inhibitor 2 & 7980 & https://www.ncbi.nlm.nih.gov/gene/7980 \\
\hline THBS1 & Thrombospondin 1 & 7057 & https://www.ncbi.nlm.nih.gov/gene/7057 \\
\hline TIMP1 & TIMP metallopeptidase inhibitor 1 & 7076 & https://www.ncbi.nlm.nih.gov/gene/7076 \\
\hline TIMP3 & TIMP metallopeptidase inhibitor 3 & 7078 & https://www.ncbi.nlm.nih.gov/gene/7078 \\
\hline VCAN & Versican & 1462 & https://www.ncbi.nlm.nih.gov/gene/1462 \\
\hline
\end{tabular}

and ADAMTS1 expressions were also associated with tumor stage [40].

Tissue inhibitors of metalloproteinases (TIMPs) as the main MMPs endogenous inhibitors bind to the enzyme catalytic site [92]. Regulation of basement membranes requires a balance between the functions of MMPs and TIMPs [93]. Up regulation of TIMP1 was reported in various tumors [94]. It has been observed that there was high levels of TIMP1 expression in GC tumors with advanced stages, increased depth of invasion, and metastatic lymph nodes. Moreover, the inflammatory infiltrate cells had higher levels of TIMP1 compared with tumor cells. Therefore, higher levels of expressions in advanced stages can be related to the synthetic role of inflammatory cells as well as tumor cells [41]. Another group has been observed that there were significant higher levels of MMP2, MMP24, and MMP25 expressions in GC compared with SG. Moreover, there were correlations between MMP14, TIMP3, and risk of GC progression [42].

Tumor progression requires networks of both the immediate (cell-cell or cell-matrix interactions) and extended microenvironment (vascularization). The stromal activation is parallel with tumor cell growth and metastasis $[95,96]$. Lysyl oxidase (LOX) is an extracellular amine oxidase and regulator of tumor microenvironment through ECM posttranslational modification which promotes tumor cell proliferation [97]. LOX also recruits bone marrow-derived cells which are involved in angiogenesis and immune cells infiltration [98]. It has been reported that the gastric tumor samples had significant higher levels of LOX expression compared with peritumoral samples. Moreover, there was a correlation between LOX over expression and local tumor relapse [43]. LOXL4 over expression was also observed in GC patients which was correlated with tumor size, depth of invasion, lymph node involvement, stage, and poor survival. Moreover, LOXL4 induces gastric tumor cell proliferation and migration through FAK/SRC pathway and ERK phosphorylation. LOXL4 can also increase GC cells adhesion with collagen I and fibronectin which is associated with gastric tumor cell migration and invasion [44]. PLOD2 is a lysyl hydroxylase that hydroxylates lysine in procollagens and is regulated by HIF1 to mediate ECM remodeling [99]. It has been shown that the PLOD2 induces GC progression in hypoxic status via HIF1A and there was a significant association between PLOD2 expression and peritoneal metastasis. The PLOD2 over expressed GC cases had also increased collagen expression in their tumor tissues which showed HIF1A/PLOD2 signaling pathway as a regulator of GC aggressiveness in a collagen-related status [45].

Tissue factor pathway inhibitor 2 (TFPI2) is a serine proteinase inhibitor involved in protection of ECM from degradation [100]. Therefore, loss of TFPI2 increases the aggressive behavior of neoplastic cells [101]. The TFPI2 methylation levels were assessed in gastric tumors compared with corresponding normal margins, which showed TFPI2 hyper methylation in majority of GC tissues. Therefore, they suggested the TFPI2 hyper methylation as an efficient diagnostic marker of GC [46]. Regarding the levels of muscularis mucosa involvement, GC is classified into intramucosal and submucosal types, in which the submucosal tumors have higher rates of lymph node involvement. ETS1 is a transcription factor associated with mesodermal development during embryogenesis [102]. It is involved in tumor invasion through regulation of several genes such as urokinase type plasminogen activator, stromelysin-1, and collagenase-1 [103, 104]. It has been reported that the ETS1 over expression induced mucosal into the submucosal tumor invasion in GC patients. Whereas, there was not any ETS1 expression in normal gastric epithelium. The submucosal carcinomas had higher levels of ETS1 compared with mucosal adenocarcinomas which suggested the role of ETS1 in local invasion to submucosa during GC progression [47]. 


\section{Extracellular angiogenic factors}

In this section, we summarize seven gene products including extracellular inducer (BSG: EMMPRIN), extracellular angiostatic protein (MMRN2), extracellular matrix glycoprotein (EMILIN2), heparinase (HPSE), collagen triple helix repeat containing 1 (CTHRC1), galectin 1 (LGLS1), and extracellular matrix protein 1 (ECM1).

Angiogenesis is a critical process during tumor growth which initiates from the outgrowth and migration of endothelial cells from parental vessels through vascular endothelial growth factor (VEGF). Cytokines, growth factors, and ECM proteins are important regulators of angiogenesis $[105,106]$. In this process the MMPs has a key function in regulation of ECM in endothelial cells to form tube-like structures and blood vessels [107]. The extracellular MMP inducer (EMMPRIN) is a transmembrane immunoglobulin expressed on activated $\mathrm{T}$ cells, macrophages, endometrium, keratinocytes, and several solid tumors which induces MMP synthesis [108, 109]. It has been shown that there was a direct correlation between BSG expression, tumor size, and VEGF expression in GC patients. Moreover, the BSG over expressed tumors had higher ability for lymph node metastasis. They concluded that the BSG increases the tumor invasion and angiogenesis through MMP and VEGF up regulations in GC cells [48].

Multimerin 2 (MMRN2) is an extracellular angiostatic protein which suppresses the VEGFA/VEGFR2 signaling pathway [110]. It has been observed that there was high expression of MMRN2 in normal gastric mucosa along blood vessels, while the EMILIN 2 and EMILIN 1 expressions were limited to the lamina propria. The loss of EDEN family significantly affects the treatments efficiency and tumor progression [49]. Heparanase (HPSE) is an angiogenic factor and cleaves heparan sulfate (HS) side chains that are one of the main components of ECM and basement membrane. HS cleavage releases HS-linked angiogenic and growth factors such as FGF and VEGF [111]. Moreover, Heparan sulfate proteoglycans are suggested to induce stem cell properties through WNT and IL6/STAT5 pathways [112]. Therefore, HS and heparanase can be associated with various processes such as cell proliferation, adhesion, migration, and angiogenesis [113, 114]. It has been shown that the GA/AA genotypes of rs11099592 polymorphism were associated with superficial invasion of GC. Moreover, there was a significant correlation between rs6856901 polymorphism of HPSE and survival [50].

Collagen triple helix repeat containing 1 (CTHRC1) is a glycoprotein containing a short collagen triple helix repeat associated with cell migration through regulation of collagen matrix deposition [115]. It also functions in cell response to the arterial injury and vascular remodeling. It has been reported that there was a direct correlation between the levels of CTHRC1 expression and deeper depths of invasion which suggested that the CTHRC1 can be involved in GC progression and metastasis. Promoter hyper methylation has an important role in CTHR C1 silencing. In vitro study also showed that the levels of CTHRC1 expression was associated with TGFB1 promoter demethylation [51]. Another study has been reported that the CTHRC1 up regulation was significantly associated with tumor stage, differentiation, survival, prognosis, depth of invasion, lymph node involvement, and tumor size among a sub population of GC patients [52]. During the metastasis process, tumor cells regulate growth factors, cytokines, ECM, and cancer-associated fibroblasts (CAFs) [116]. Galectin 1 (LGALS1) is a carbohydrate-binding lectin which is up regulated in CAFs and induces angiogenesis $[117,118]$. Hh signaling pathway has a critical function during the EMT, angiogenesis, and tumor progression of GC through glioma-associated oncogene 1 (GLI1) [117-120]. The $\beta 1$ integrin is a cell surface adhesion receptors which is inversely associated with cell adhesion loss and has a lactosamine sequence [121]. It has been shown that the CAFs induce epithelial to fibroblastoid phenotype, decrease Ecadherin, and increase vimentin in microenvironment through secretion of LGALS1 that functions via binding to the lactosamine sequence of $\beta 1$ integrin [121-123]. Moreover, LGALS1 up regulated the GLI1 in GC cells introducing a key role of LGALS1 in GC metastasis through binding with $\beta 1$ integrin [122].

Extracellular matrix protein 1 (ECM1) is involved in cell proliferation, migration, angiogenesis, and EMT [124]. During EMT process, cells change their epithelial properties to mesenchymal invasive phenotype via down regulation of E-cadherin and upregulation of vimentin [125]. ECM1 is also associated with glucose metabolism via LDHA, GLUT1, and HIF1A [126]. The ECM1 enhances the EMT and glucose metabolism through up regulation of ITGB4 and activation of FAK/SOX2 signaling pathway. Subsequent, SOX2 up regulation regulates HIF1A, vimentin, $\beta$-catenin, and E-cadherin expressions. It has been observed that there were correlations between high ECM1 levels, tumor relapse, poor survival, and advanced stages of tumor among GC patients [53]. Lymphangiogenesis is a critical step during tumor progression that prepares more opportunities for tumor cells to spread using lymphatic system [127, 128]. ECM1 has also an important role in lymphangiogenesis [129]. It has been shown that the GC tumor tissues had significantly higher levels of ECM1 expressions compared with normal margins. There were also significant correlations between ECM1 expression, tumor depth of invasion, and stage [54]. CXCR1 and CXCR2 are IL-8 receptors associated with poor prognosis of GC [130]. CXCR1 is a G protein-coupled receptor involved in signal transduction [131], while CXCR2 is a G protein-coupled receptor associated with inflammation and angiogenesis [132]. It 
has been shown that there were significant correlations between CXCR1, CXCR2, and MMP9 expressions in which CXCR1 and CXCR2 induce MMP9 expression through JNK/c-JUN and ERK/ETS1 signaling pathways [133-135].

\section{Cell adhesion and cytoskeletal organizers}

In this section, we summarize 13 gene products including a member of the protocadherin alpha gene cluster (PCDH8), laminin subunit gamma 2 (LAMC2), a claudin family member (CLDN4), cellular adhesion proteins (LLGL1 and ANOS1), fibronectin family members (FN1 and FNDC1), integrin alpha chain member (ITGA4), immunoglobulin family [ICAM1 (CD54)], cytoskeletal reorganizer (CFL1), hyaluronan mediated motility receptor (HMMR), microfibril associated protein (MFAP2), and an integrin ligand (SPON2).

Epithelial cell junctions have various functions such as communication, anchoring, and sealing. E-cadherin is the main protein of adherent junctions to stabilize the basolateral cell-cell contact. Therefore, E-cadherin loss increases cell migration [136]. Protocadherin (PCDH) is a member of the protocadherin alpha gene cluster functioning as tumor suppressors or oncogenes. They have an apoptotic role by inhibition of WNT pathway, or induce cell migration and drug resistance $[137,138]$. It has been shown that the PCDH8 up regulation was significantly associated with poor prognosis and GC migration through up regulation of LAMC2 [55]. Claudins are the main components of tight junctions in epithelial and endothelial cell membranes which functions as primary barriers and regulate the polarity of epithelial cells $[139,140]$. The claudin interacts with variety of proteins such as $\mathrm{ZO}$ proteins, RAB3B, PTEN, and ZONAB [141, 142]. It has been shown that there were associations between Claudin 4 (CLDN4) expression, depth of invasion, lymph node involvement, and MMP2,9 expressions which suggested the CLDN4 as a regulator of MMP2 and - 9 expressions [56].

LLGL1 is also a cellular adhesion protein that is involved in epithelial cell polarity and migration through a polarity complex comprising of PAR6, PAR3, PKC, and LLGL [143, 144]. It has been shown that there were significant correlations between LLGL1 loss, distant metastasis, and diffuse type of GC [57]. Fibronectin (FN) as a structural basement membrane glycoprotein has a critical function in cell adhesion, migration, and embryogenesis through cell surface receptors and integrins [145]. It is required for the proper collagen incorporation with ECM [146]. Fibronectin and collagen bind to integrins which are involved in cell-matrix adhesion and signal transduction [147, 148]. Fibronectin is also involved in cell proliferation and migration through mTOR signaling pathway $[149,150]$. As a mesenchymal marker, it promotes TGF $\beta$ during EMT [151]. FN1 is also activator of STAT3 and MAPK signaling pathways to promote tumor progression and metastasis [152]. It has been observed that there was increased serum levels of fibronectin among GC patients which can be introduced as a diagnostic marker [58]. Fibronectin type III domain containing 1 (FNDC1) contains the type III domain of fibronectin [145]. It has been observed that there was significant higher levels of FNDC1 expression in GC compared with normal tissues. Moreover, there were significant correlations between FNDC1 expression, sex, survival, and tumor stage in GC patients [59].

The Anosmin 1 (ANOS1) is a cell adhesion protein associated with migration of gonadotropin-releasing hormone neurons. It increases the malignant behavior through integrin signaling pathways in brain tumors and promotes cell migration and drug resistance in colon cancer $[153,154]$. It has been reported that there were increased levels of ANOS1 expressions in GC cell lines in comparison with normal epithelial cell line which suggested ANOS1 as an oncogene in GC. The GC tissues also showed ANOS1 over expression which was correlated with tumor stage, prognosis, and diffuse type. PCR array also showed ITGAV, FOXC2, and NODAL expressions parallel with ANOS1, while TFPI2 down regulation [60]. ITGAV is a member of the ECM and involved in EMT [155]. The FOXC2 is an important transcription factor during EMT [156]. NODAL is belonged to the TGF- $\beta$ family which has key role in cell growth and migration [157]. Integrins are cell-surface receptors involving in cell-cell and cell-ECM interactions and tumor metastasis $[158,159]$. It has been reported that the ITGA4 expression is lost in the majority of GC cell lines and tumor tissues through DNA methylation [61].

Leptin is an adipokine that is involved in body weight homeostasis through regulation of energy metabolism [160]. Leptin also has a key role in cell migration via up regulation of CD54 in allergic inflammation [161]. ICAM1 (CD54)is belonged to the immunoglobulin family which binds with ITGB2 and ITGAM to facilitate the metastasis and hiding toward immunocytes [162]. It functions as an intercellular adhesion protein and has inhibitory role on tight junction formation in blood-testis barrier during spermatogenesis [163]. Various factors such as RHO and ROCK regulate the ICAM1 expression [164]. It has been shown that the leptin induces GC migration through up regulation of ICAM1 and activation of $\mathrm{RHO} / \mathrm{ROCK}$ signaling pathway. Moreover, there were correlations between ICAM1 levels, stage, and lymph node involvement in GC patients [62].

Cofilin 1 (CFL1) is a cytoskeletal reorganizer and EMT regulator in tumor cells [165]. It has been shown that there were consistent CFL1 up regulation in GC tissues. TGFB1 induced CFL1 expression in the gastric tumor cells. The lack of CFL1 inhibited actin depolymerization and microfilaments function. G-actin can be irreversibly aggregated into F-actin which blocks the cell surface pseudopodia formation. TGFB1 up regulated the CFL1, 
G-actin, and F-actin expressions which resulted in microfilament polymerization. Therefore, it was concluded that CFL1 promotes the EMT process and gastric tumor cell invasion through cytoskeletal rearrangement [63]. Hyaluronic acid (HA) as an ECM component is mainly secreted by fibroblasts in response to humoral signals of tumor cells [166]. HMMR is an intracellular HA binding protein belonging to the microtubuleassociated protein (MAP) family which is associated with microfilament formation and cell movement in tumor cells. An expressional study has been performed on the levels of HMMR protein expressions in GC patients and showed positive expression in cellular mucosa and cytoplasm in tumor cells, while it was expressed rarely in normal gastric mucosa. There was also a significant converse correlation between HMMR expression and lymph node involvement [64].

Microfibril associated protein 2 (MFAP2) is one of the main regulators of microfibril function which binds with ECM and TGF- $\beta$ through specific domains in carboxyl and amino-terminal, respectively $[167,168]$. It has been reported that there was MFAP2 up regulation in GC tissues which was associated with depth of invasion, lymph node involvement, tumor stage, and poor survival. Moreover, MFAP2 induces the EMT process and gastric tumor cell proliferation through TGF- $\beta / \mathrm{SMAD} 2 / 3$ signaling pathway. The MFAP2 knockdown significantly modulated the EMT factors in which Vimentin and Snail expressions were decreased while E-cadherin was up regulated [65]. Spondin 2 (SPON2) is a secreted ECM protein belonged to the F-spondin family which is an integrin ligand [169]. It has been observed that there was SPON2 increased expression in GC tissues in comparison with the normal margins. There were significant correlations between SPON2 up regulation, grade of tumor differentiation, depth of invasion, lymph node involvement, and advanced stages in GC cases. The cases with SPON2 over expression had lower survival compared with under expressed GC patients. The tumors with advanced depth of invasion and metastatic lymph nodes had increased levels of SPON2 expression. Moreover, they showed that there was a direct association between SPON2 and MMP9 expressions among GC patients [66].

\section{Matricellular proteins and growth factors}

In this section, we summarize seven matricellular protein gene products including secreted protein acidic and cysteine rich (SPARC), SPARC like protein 1 (SPARCL1), serpin family E member 1 (SERPINE1), fibroblast growth factor receptor 2 (FGFR2), thrombospondin 1 (THBS1), latent transforming growth factor beta binding protein 2 (LTBP2), and periostin (POSTN).
Matricellular proteins are ECM glycoproteins that includes osteopontin, tenascins, POSTN, SPARC, and thrombospondins that are associated with embryogenesis, stem cell niches, and tissue remodeling [79, 170]. Most of them regulate cell-matrix adhesions via binding with fibronectin or collagen. SPARC is a matricellular protein produced by endothelial cells which regulates cell-matrix interactions during tissue remodeling through binding with ECM components such as collagens and fibronectin $[171,172]$. It has been shown that there was increased expression of SPARC in GC tissues in comparison with normal margins. There were correlations between SPARC up regulation, serosal invasion, poor survival [67]. SERPINE1 and SPARC over expressions were also observed in GC tissues which were correlated with poor survival [68]. SPARC like protein 1 (SPARCL1) is a matricellular protein involving in tumor progression and tissue regeneration [173]. It has been reported that there was decreased expression of SPARCL1 in GC tissues compared with normal margins. There were significant correlations between SPARCL1 down regulation, poor prognosis, survival, histological type, and tumor size. There was also an association between SPARCL1 expression and grade of tumor differentiation in which there was a significant declining levels of expression toward the poorly differentiated tumors [69]. The thrombospondin is a calcium binding glycoprotein involving in wound healing and angiogenesis in which it inhibits angiogenesis via interaction with CD36 on endothelial cells and promoting apoptosis [174]. Fibroblast growth factors (FGFs) are heparin-binding growth factors involving in cell proliferation and angiogenesis through FGF receptors (FGFRs). FGF7 as a keratinocyte growth factor promotes FGFR2 dimerization and initiates various signaling pathways such as MAPK and PI3K/Akt $[175,176]$. Thrombospondin 1(THBS1) is an endogenous angiogenesis inhibitor [177] which is associated with FGF7/FGFR2 during GC migration and invasion. It has been shown that there were higher levels of FGFR2 and THBS1 expressions in GC tumors compared with normal margins. There was an association between THBS1 expression and well/moderate differentiation which suggests a less aggressive behavior. Since there was a direct correlation between THBS1 and FGFR2 expressions, the FGF7/FGFR2 may induce GC invasion through THBS1. Moreover, it was shown that the FGF7/ FGFR2 up regulates THBS1 through PI3K/Akt/mTOR pathway [70].

LTBP2 is belonged to the ECM proteins which has calcium-binding epidermal growth factor like and TGF$\beta$ binding domains [178]. LTBPs have an important role in ECM regulation and TGF- $\beta$ activation [179]. It has been reported that there were increased expression of LTBP2 in GC tissues and cell lines which was correlated 
with depth of invasion, lymph node involvement, poor survival, and tumor stage [71]. POSTN is one of the ECM components that has oncogenic role through integrins and EGFR to activate the AKT/PKB and FAK signaling pathways in different tumors [180, 181]. It has been shown that there were lower levels of periglandular POSTN expression in GC tissues compared with normal margins. The metastatic lymph nodes had significantly lower levels of POSTN expression. Moreover, there was an inverse correlation between POSTN expression and tumor stage. It seems that this tumor suppressor role of POSTN can be related to the probable correlation between POSTN, P53, and E-cadherin through Rb/E2F1/ p14ARF/MDM2 signaling pathway [72].

\section{Proteoglycans and extra cellular glycoproteins}

In this section, we summarize four matricellular protein gene products including versican (VCAN), asporin (ASPN), lumican (LUM), and mucin 2 (MUC2).

The ECM is composed of various proteins such as proteoglycans (PGs) and collagens that organize physiological and pathological functions [182]. Proteoglycans are glycosylated proteins spreading throughout the mammalian tissues which are associated with tissue remodeling, cellular adhesion, and signaling pathways. VCAN as a chondroitin sulfate PG is mainly accumulated in tumor stroma and has key functions in regulation of cell proliferation, self-renewal, and migration $[183,184]$. It has been shown that the GC tissues had significantly higher levels of VCAN expression. Moreover, there was a correlation between VCAN over expression and GC poor prognosis [73].

Asporin (ASPN) is one of the members of small Leucine-rich proteoglycan (SLRP) family that is associated with ECM modification [185]. It has been reported that there was significantly increased levels of ASPN expression in GC tissues compared with normal margins. The migration of gastric tumor cells also significantly decreased following the ASPN knockdown. Moreover, it seems that there were some correlations between CD44, MMP2, and ASPN expression in which ASPN silencing significantly decreased the levels of CD44 and MMP2 expressions in GC cells. Therefore in can be concluded that the ASPN is involved in regulation of GC migration and metastasis via EGFR-CD44/MMP2 signaling pathway [74]. Cancer-associated fibroblasts (CAFs) are stromal cells characterized by their spindle-shape morphology, fibroblast activation protein alpha, and $\alpha$-smooth muscle actin expressions [186]. These cells are associated with tumor progression via secretion of several factors such as cytokines and growth factors [187]. LUM is an external proteoglycan belonged to the SLRPs family. It seems that the LUM exerts its role in gastric tumor progression through integrin $\beta 1$-FAK signaling pathway. FAK as a tyrosine kinase is activated by integrin or growth factor receptors and has key role in regulation of cyclins and signaling pathways such as PI3K/AKT and MAPK $[188,189]$. It has been observed that there was LUM up regulation in gastric CAFs which was directly correlated with advanced stage, poor survival, depth of invasion, and lymph node involvement. LUM knockdown in CAFs also suppresses the GC cell proliferation, migration, and in vivo tumorigenesis [75].

Mucins are glycoproteins comprising of a mucin core and O-linked oligosaccharides produced by epithelial tissues which are involved in epithelial surfaces protection, inflammation, renewal, and tumorigenesis [190]. Although, expressions of MUC1, MUC5AC, and MUC6 are observed in normal gastric mucosa [191], there is not any MUC2 expression in normal gastric mucosa [192]. It has been observed that majority of GC tissues had MUC2 expression. Moreover, MUC2 reactivity was directly correlated with grade of differentiation [76]. Sialic acids are monosaccharides that are attached to the membranous glycoproteins and glycolipids. It has been shown that there was a correlation between tumor invasion and deregulation of terminal 2, 3-linked sialic acids [193, 194]. The up regulation of 2, 3-linked sialic acid residues were associated with lymph node involvement and depth of tumor invasion. MAL as a specific sialic acid-binding lectin was observed in gastric cancerous regions, whereas it was not detected in normal margins [195].

\section{Conclusion}

Regarding the importance of extra cellular matrices and components in GC metastasis and invasion, in present review we summarized 48 of significant ECM related factors which have been reported among GC patients. It has been shown that the intra cellular signaling pathways associated with tumor invasion also exert their role through regulation of local ECM. Therefore, according to the lower complexity of ECM compared with intracellular signaling pathways, the ECM can be a more reliable tumor therapeutic target with lower side effects. Indeed this review paves the way of introducing an extra cellular based prognostic and diagnostic panel marker for the GC patients.

\footnotetext{
Abbreviations

ANOS1: Anosmin 1; ASPN: Asporin; CAFs: Cancer-associated fibroblasts;

CFL1: Cofilin 1; COX2: Cyclooxygenase 2; CTHRC1: Collagen triple helix repeat containing 1; ECM: Extracellular matrix; ECM1: Extracellular matrix protein 1;

EMMPRIN: Extracellular MMP inducer; EMT: Epithelial-mesenchymal transition; FGFs: Fibroblast growth factors; FGFRs: FGF receptors; FN: Fibronectin; FNDC1: Fibronectin type III domain containing 1; GC: Gastric cancer; GLI1: GLI family zinc finger 1; HA: Hyaluronic acid; HMMR: Hyaluronan mediated motility receptorHPSEHeparanase; LAMC2: Laminin subunit gamma 2; LGALS1: Galectin 1; LUM: Lumican; MAP: Microtubule associated protein; MFAP2: Microfibril associated protein 2; MMPs: Matrix metalloproteinases; MMRN2: Multimerin 2; PCDH: Protocadherins; PGs: Proteoglycans; POSTN: Periostin; SLRP: Small Leucine-rich proteoglycan; SPON2: Spondin 2; SPARCL1: SPARC like protein 1; TFPI2: Tissue factor pathway inhibitor 2;
} 
THBS1: Thrombospondin 1; TIMPs: Tissue inhibitors of metalloproteinases; VCAN: Versican; VEGF: Vascular endothelial growth factor

\section{Acknowledgements \\ Not applicable.}

\section{Authors' contributions}

MMoghbeli, MMojarrad, and MRA were involved in drafting and edition. The authors read and approved the final manuscript.

\section{Funding}

Not applicable.

\section{Availability of data and materials}

The datasets used and/or analyzed during the current study are available from the corresponding author on reasonable request.

\section{Ethics approval and consent to participate}

Not applicable.

\section{Consent for publication}

Not applicable.

\section{Competing interests}

The authors declare that they have no competing interests.

\section{Author details}

Medical Genetics Research Center, Mashhad University of Medical Sciences, Mashhad, Iran. Department of Medical Genetics and Molecular Medicine, School of Medicine, Mashhad University of Medical Sciences, Mashhad, Iran.

\section{Received: 29 January 2020 Accepted: 5 May 2020}

\section{Published online: 15 May 2020}

\section{References}

1. Bissell MJ, Labarge MA. Context, tissue plasticity, and cancer: are tumor stem cells also regulated by the microenvironment? Cancer cell. 2005;7(1): 17-23.

2. Hynes RO. The extracellular matrix: not just pretty fibrils. Science. 2009; 326(5957):1216-9.

3. Cox TR, Erler JT. Remodeling and homeostasis of the extracellular matrix implications for fibrotic diseases and cancer. Dis Model Mech. 2011;4(2): 165-78.

4. Moghbeli M, Moaven O, Memar B, Raziei HR, Aarabi A, Dadkhah E, et al. Role of hMLH1 and E-cadherin promoter methylation in gastric cancer progression. J Gastrointest Cancer. 2014;45(1):40-7.

5. Ozbek S, Balasubramanian PG, Chiquet-Ehrismann R, Tucker RP, Adams JC The evolution of extracellular matrix. Mol Biol Cell. 2010;21(24):4300-5.

6. Aitken KJ, Bagli DJ. The bladder extracellular matrix. Part I: architecture development and disease. Nat Rev Urol. 2009;6(11):596-611..

7. Page-McCaw A, Ewald AJ, Werb Z. Matrix metalloproteinases and the regulation of tissue remodelling. Nat rev Mol Cell Biol. 2007:8(3):221-33.

8. Egeblad M, Rasch MG, Weaver VM. Dynamic interplay between the collagen scaffold and tumor evolution. Curr Opin Cell Biol. 2010;22(5):697-706.

9. Wyckoff JB, Wang Y, Lin EY, Li JF, Goswami S, Stanley ER, et al. Direct visualization of macrophage-assisted tumor cell intravasation in mammary tumors. Cancer Res. 2007:67(6):2649-56

10. Huijbers IJ, Iravani M, Popov S, Robertson D, Al-Sarraj S, Jones C, et al. A role for fibrillar collagen deposition and the collagen internalization receptor endo180 in glioma invasion. PloS one. 2010;5(3):e9808.

11. Radisky ES, Radisky DC. Matrix metalloproteinase-induced epithelialmesenchymal transition in breast cancer. J Mammary Gland Biol Neoplasia. 2010;15(2):201-12

12. Sternlicht MD, Lochter A, Sympson CJ, Huey B, Rougier JP, Gray JW, et al. The stromal proteinase MMP3/stromelysin-1 promotes mammary carcinogenesis. Cell. 1999;98(2):137-46.

13. Moghbeli M, Forghanifard MM, Sadrizadeh A, Mozaffari HM, Golmakani E, Abbaszadegan MR. Role of Msi1 and MAML1 in regulation of notch signaling pathway in patients with esophageal squamous cell carcinoma. J Gastrointest Cancer. 2015;46(4):365-9.
14. Moghbeli M, Mosannen Mozaffari H, Memar B, Forghanifard MM, Gholamin M, Abbaszadegan MR. Role of MAML1 in targeted therapy against the esophageal cancer stem cells. J Transl Med. 2019;17(1):126.

15. Mott JD, Werb Z. Regulation of matrix biology by matrix metalloproteinases. Curr Opin Cell Biol. 2004;16(5):558-64.

16. Keely PJ. Mechanisms by which the extracellular matrix and integrin signaling act to regulate the switch between tumor suppression and tumor promotion. J Mammary Gland Biol Neoplasia. 2011;16(3):205-19.

17. Schwartz MA, Assoian RK. Integrins and cell proliferation: regulation of cyclin-dependent kinases via cytoplasmic signaling pathways. J Cell Sci. 2001;114(Pt 14):2553-60.

18. Dangerfield J, Larbi KY, Huang MT, Dewar A, Nourshargh S. PECAM-1 (CD31) homophilic interaction up-regulates alpha6beta1 on transmigrated neutrophils in vivo and plays a functional role in the ability of alpha6 integrins to mediate leukocyte migration through the perivascular basement membrane. J Exp Med. 2002;196(9):1201-11.

19. Birnbaum LS. State of the science of endocrine disruptors. Environ Health Perspect. 2013;121(4):A107.

20. Le Bitoux MA, Stamenkovic I. Tumor-host interactions: the role of inflammation. Histochem Cell Biol. 2008;130(6):1079-90.

21. Olumi AF, Grossfeld GD, Hayward SW, Carroll PR, Tlsty TD, Cunha GR. Carcinoma-associated fibroblasts direct tumor progression of initiated human prostatic epithelium. Cancer Res. 1999:59(19):5002-11.

22. Weaver VM, Gilbert $P$. Watch thy neighbor: cancer is a communal affair. J Cell Sci. 2004;117(Pt 8):1287-90.

23. Duffield JS, Lupher M, Thannickal VJ, Wynn TA. Host responses in tissue repair and fibrosis. Annu Rev Pathol. 2013;8:241-76.

24. Atkinson MJ. Radiation treatment effects on the proteome of the tumour microenvironment. Adv Exp Med Biol. 2013:990:49-60.

25. Jensen K, Nizamutdinov D, Guerrier M, Afroze S, Dostal D, Glaser S. General mechanisms of nicotine-induced fibrogenesis. FASEB J. 2012;26(12):4778-87.

26. Casey SC, Vaccari M, Al-Mulla F, Al-Temaimi R, Amedei A, Barcellos-Hoff MH, et al. The effect of environmental chemicals on the tumor microenvironment. Carcinogenesis. 2015;36(Suppl 1):S160-83.

27. Torre LA, Bray F, Siegel RL, Ferlay J, Lortet-Tieulent J, Jemal A. Global cancer statistics, 2012. CA Cancer J Clin. 2015:65(2):87-108.

28. Bernards N, Creemers GJ, Nieuwenhuijzen GA, Bosscha K, Pruijt JF, Lemmens VE. No improvement in median survival for patients with metastatic gastric cancer despite increased use of chemotherapy. Ann Oncol. 2013;24(12): 3056-60.

29. Martella L, Bertozzi S, Londero AP, Steffan A, De Paoli P, Bertola G. Surgery for liver metastases from gastric Cancer: a meta-analysis of observational studies. Medicine. 2015;94(31):e1113.

30. Riihimaki M, Hemminki A, Sundquist K, Sundquist J, Hemminki K. Metastatic spread in patients with gastric cancer. Oncotarget. 2016;7(32):52307-16.

31. Leeming DJ, Bay-Jensen AC, Vassiliadis E, Larsen MR, Henriksen K, Karsda MA. Post-translational modifications of the extracellular matrix are key events in cancer progression: opportunities for biochemical marker development. Biomarkers. 2011:16(3):193-205.

32. Matsumura S, Oue N, Nakayama H, Kitadai Y, Yoshida K, Yamaguchi $Y$, et al. A single nucleotide polymorphism in the MMP-9 promoter affects tumor progression and invasive phenotype of gastric cancer. J Cancer Res Clin Oncol. 2005:131(1):19-25.

33. Mroczko B, Lukaszewicz-Zajac M, Guzinska-Ustymowicz K, Gryko M, Czyzewska J, Kemona A, et al. Expression of matrix metalloproteinase-9 in the neoplastic and interstitial inflammatory infiltrate cells in gastric cancer. Folia Histochem Cytobiol. 2009:47(3):491-6.

34. Dragutinovic $V$, Izrael-Zivkovic L, Radovanovic N. Relation of matrix metalloproteinase-9 to different stages of tumors in the serum of gastric cancer. Dig Dis Sci. 2009;54(6):1203-7.

35. Matsumura S, Oue N, Kitadai Y, Chayama K, Yoshida K, Yamaguchi Y, et al. A single nucleotide polymorphism in the MMP-1 promoter is correlated with histological differentiation of gastric cancer. J Cancer Res Clin Oncol. 2004; 130(5):259-65.

36. Dedong H, Bin Z, Peisheng S, Hongwei X, Qinghui $Y$. The contribution of the genetic variations of the matrix metalloproteinase-1 gene to the genetic susceptibility of gastric cancer. Genet Test Mol Biomarkers. 2014; 18(10):675-82.

37. Mrena J, Wiksten JP, Nordling S, Kokkola A, Ristimaki A, Haglund C. MMP-2 but not MMP-9 associated with COX-2 and survival in gastric cancer. J Clin Pathol. 2006;59(6):618-23. 
38. Kasurinen A, Tervahartiala T, Laitinen A, Kokkola A, Sorsa T, Bockelman C, et al. High serum MMP-14 predicts worse survival in gastric cancer. PloS one. 2018;13(12):e0208800.

39. Sentani K, Matsuda M, Oue N, Uraoka N, Naito Y, Sakamoto N, et al. Clinicopathological significance of MMP-7, laminin gamma2 and EGFR expression at the invasive front of gastric carcinoma. Gastric Cancer. 2014; 17(3):412-22.

40. Kilic MO, Aynekin B, Kara A, Icen D, Demircan K. Differentially regulated ADAMTS1, 8, and 18 in gastric adenocarcinoma. Bratisl Lek Listy. 2017; 118(2):71-6.

41. Mroczko B, Lukaszewicz-Zajac M, Groblewska M, Czyzewska J, Gryko M, Guzinska-Ustymowicz K, et al. Expression of tissue inhibitors of metalloproteinase 1 (TIMP-1) in gastric cancer tissue. Folia histochemica et cytobiologica. 2009;47(3):511-6.

42. de la Pena S, Sampieri CL, Ochoa-Lara M, Leon-Cordoba K, Remes-Troche JM. Expression of the matrix metalloproteases 2, 14, 24, and 25 and tissue inhibitor 3 as potential molecular markers in advanced human gastric cancer. Dis Markers. 2014;2014:285906.

43. Peng C, Liu J, Yang G, Li Y. Lysyl oxidase activates cancer stromal cells and promotes gastric cancer progression: quantum dot-based identification of biomarkers in cancer stromal cells. Int J Nanomed. 2018;13:161-74.

44. Li RK, Zhao WY, Fang F, Zhuang C, Zhang XX, Yang XM, et al. Lysyl oxidaselike 4 (LOXL4) promotes proliferation and metastasis of gastric cancer via FAK/Src pathway. J Cancer Res Clin Oncol. 2015;141(2):269-81.

45. Kiyozumi Y, Iwatsuki M, Kurashige J, Ogata Y, Yamashita K, Koga Y, et al. PLOD2 as a potential regulator of peritoneal dissemination in gastric cancer. Int J Cancer. 2018;143(5):1202-11.

46. Hu H, Chen $X$, Wang $C$, Jiang $Y$, Li J, Ying $X$, et al. The role of TFPI2 hypermethylation in the detection of gastric and colorectal cancer. Oncotarget. 2017:8(48):84054-65.

47. Nakayama T, Ito M, Ohtsuru A, Naito S, Nakashima M, Fagin JA, et al. Expression of the Ets-1 proto-oncogene in human gastric carcinoma: correlation with tumor invasion. Am J Pathol. 1996;149(6):1931-9.

48. Zheng HC, Takahashi H, Murai Y, Cui ZG, Nomoto K, Miwa S, et al Upregulated EMMPRIN/CD147 might contribute to growth and angiogenesis of gastric carcinoma: a good marker for local invasion and prognosis. Br J Cancer. 2006;95(10):1371-8.

49. Andreuzzi E, Capuano A, Pellicani R, Poletto E, Doliana R, Maiero S, et al. Loss of Multimerin-2 and EMILIN-2 Expression in Gastric Cancer Associate with Altered Angiogenesis. Int J Mol Sci. 2018;19(12).

50. Yue $Z$, Song $Y$, Wang $Z$, Luo $Y$, Jiang $L$, Xing $L$, et al. Association of heparanase gene (HPSE-1) single nucleotide polymorphisms with gastric cancer. J Surg Oncol. 2010;102(1):68-72.

51. Wang $P$, Wang $Y C$, Chen $X Y$, Shen $Z Y$, Cao H, Zhang $Y$ J, et al. CTHRC1 is upregulated by promoter demethylation and transforming growth factorbeta1 and may be associated with metastasis in human gastric cancer. Cancer Sci. 2012;103(7):1327-33.

52. Gu L, Liu L, Zhong L, Bai $Y$, Sui $H$, Wei $X$, et al. Cthrc1 overexpression is an independent prognostic marker in gastric cancer. Human Pathol. 2014;45(5): 1031-8.

53. Gan L, Meng J, Xu M, Liu M, Qi Y, Tan C, et al. Extracellular matrix protein 1 promotes cell metastasis and glucose metabolism by inducing integrin beta4/FAK/SOX2/HIF-1alpha signaling pathway in gastric cancer. Oncogene. 2018;37(6):744-55.

54. Wu Q, Li X, Yang H, Lu C, You J, Zhang Z. Extracellular matrix protein 1 is correlated to carcinogenesis and lymphatic metastasis of human gastric cancer. World J Surg Oncol. 2014;12:132.

55. Lin Y, Ge X, Zhang X, Wu Z, Liu K, Lin F, et al. Protocadherin-8 promotes invasion and metastasis via laminin subunit gamma2 in gastric cancer. Cancer Sci. 2018;109(3):732-40.

56. Hwang TL, Lee LY, Wang CC, Liang Y, Huang SF, Wu CM. Claudin-4 expression is associated with tumor invasion, MMP-2 and MMP-9 expression in gastric cancer. Exp Ther Med. 2010;1(5):789-97.

57. Desuki A, Staib F, Gockel I, Moehler M, Lang H, Biesterfeld S, et al. Loss of LLGL1 expression correlates with diffuse gastric Cancer and distant peritoneal metastases. Can J Gastroenterol Hepatol. 2019;2019:2920493.

58. Tas F, Bilgin E, Karabulut S, Tastekin D, Duranyildiz D. Levels of serum fibronectin as a biomarker in gastric cancer patients: correlation with clinical diagnosis and outcome. Mol Clin Oncol. 2016;4(4):655-9.

59. Ren J, Niu G, Wang X, Song T, Hu Z, Ke C. Overexpression of FNDC1 in gastric Cancer and its prognostic significance. J Cancer. 2018;9(24):4586-95.
60. Kanda M, Shimizu D, Fujii T, Sueoka S, Tanaka Y, Ezaka K, et al. Function and diagnostic value of Anosmin-1 in gastric cancer progression. Int J Cancer. 2016;138(3):721-30.

61. Park J, Song SH, Kim TY, Choi MC, Jong HS, Kim TY, et al. Aberrant methylation of integrin alpha4 gene in human gastric cancer cells. Oncogene. 2004;23(19):3474-80.

62. Dong Z, Fu S, Xu X, Yang Y, Du L, Li W, et al. Leptin-mediated regulation of ICAM-1 is rho/ROCK dependent and enhances gastric cancer cell migration. Br J Cancer. 2014;110(7):1801-10.

63. Wang H, Tao L, Jin F, Gu H, Dai X, Ni T, et al. Cofilin 1 induces the epithelialmesenchymal transition of gastric cancer cells by promoting cytoskeletal rearrangement. Oncotarget. 2017;8(24):39131-42.

64. Ishigami S, Ueno S, Nishizono Y, Matsumoto M, Kurahara H, Arigami T, et al. Prognostic impact of CD168 expression in gastric cancer. BMC Cancer. 2011; 11:106.

65. Wang JK, Wang WJ, Cai HY, Du BB, Mai P, Zhang LJ, et al. MFAP2 promotes epithelial-mesenchymal transition in gastric cancer cells by activating TGFbeta/SMAD2/3 signaling pathway. Onco Targets Ther. 2018;11:4001-17.

66. Jin $C$, Lin JR, Ma L, Song $Y$, Shi $Y X$, Jiang $P$, et al. Elevated spondin-2 expression correlates with progression and prognosis in gastric cancer. Oncotarget. 2017;8(6):10416-24.

67. Sato T, Oshima T, Yamamoto N, Yamada T, Hasegawa S, Yukawa N, et al. Clinical significance of SPARC gene expression in patients with gastric cancer. J Surg Oncol. 2013;108(6):364-8.

68. Liao P, Li W, Liu R, Teer JK, Xu B, Zhang W, et al. Genome-scale analysis identifies SERPINE1 and SPARC as diagnostic and prognostic biomarkers in gastric cancer. Onco Targets Ther. 2018;11:6969-80.

69. Li P, Qian J, Yu G, Chen Y, Liu K, Li J, et al. Down-regulated SPARCL1 is associated with clinical significance in human gastric cancer. J Surg Oncol. 2012;105(1):31-7.

70. Huang T, Wang L, Liu D, Li P, Xiong H, Zhuang L, et al. FGF7/FGFR2 signal promotes invasion and migration in human gastric cancer through upregulation of thrombospondin-1. Int J Oncol. 2017;50(5):1501-12.

71. Wang J, Liang WJ, Min GT, Wang HP, Chen W, Yao N. LTBP2 promotes the migration and invasion of gastric cancer cells and predicts poor outcome of patients with gastric cancer. Int J Oncol. 2018;52(6):1886-98.

72. Lv H, Liu R, Fu J, Yang Q, Shi J, Chen P, et al. Epithelial cell-derived periostin functions as a tumor suppressor in gastric cancer through stabilizing p53 and E-cadherin proteins via the Rb/E2F1/p14ARF/Mdm2 signaling pathway. Cell Cycle. 2014;13(18):2962-74

73. Shen $X H$, Lin WR, Xu MD, Qi P, Dong L, Zhang QY, et al. Prognostic significance of Versican expression in gastric adenocarcinoma. Oncogenesis. 2015:4:e178.

74. Ding Q, Zhang M, Liu C. Asporin participates in gastric cancer cell growth and migration by influencing EGF receptor signaling. Oncol Rep. 2015;33(4): 1783-90.

75. Wang X, Zhou Q, Yu Z, Wu X, Chen X, Li J, et al. Cancer-associated fibroblast-derived Lumican promotes gastric cancer progression via the integrin beta1-FAK signaling pathway. Int J Cancer. 2017;141(5):998-1010.

76. Khattab AZ, Nasif WA, Lotfy M. MUC2 and MUC6 apomucins expression in human gastric neoplasm: an immunohistochemical analysis. Med Oncol. 2011;28(Suppl 1):S207-13.

77. Bonnans C, Chou J, Werb Z. Remodelling the extracellular matrix in development and disease. Nat Rev Mol Cell Biol. 2014;15(12):786-801.

78. Gomes AM, Stelling MP, Pavao MS. Heparan sulfate and heparanase as modulators of breast cancer progression. BioMed Res Int. 2013;2013:852093.

79. Oskarsson T. Extracellular matrix components in breast cancer progression and metastasis. Breast. 2013;22(Suppl 2):S66-72.

80. Egeblad M, Werb Z. New functions for the matrix metalloproteinases in cancer progression. Nat Rev Cancer. 2002;2(3):161-74.

81. Vincenti MP, Brinckerhoff CE. Transcriptional regulation of collagenase (MMP-1, MMP-13) genes in arthritis: integration of complex signaling pathways for the recruitment of gene-specific transcription factors. Arthritis Res. 2002;4(3):157-64.

82. Forget MA, Desrosiers RR, Beliveau R. Physiological roles of matrix metalloproteinases: implications for tumor growth and metastasis. Can J Physiol Pharmacol. 1999;77(7):465-80.

83. Curran S, Murray Gl. Matrix metalloproteinases in tumour invasion and metastasis. J Pathol. 1999;189(3):300-8.

84. Rutter JL, Benbow U, Coon Cl, Brinckerhoff CE. Cell-type specific regulation of human interstitial collagenase-1 gene expression by interleukin-1 beta 
(IL-1 beta) in human fibroblasts and BC-8701 breast cancer cells. J Cell Biochem. 1997;66(3):322-36.

85. Tryggvason K, Hoyhtya M, Pyke C. Type IV collagenases in invasive tumors. Breast Cancer Res Treat. 1993;24(3):209-18.

86. Callejas NA, Casado M, Diaz-Guerra MJ, Bosca L, Martin-Sanz P. Expression of cyclooxygenase-2 promotes the release of matrix metalloproteinase-2 and -9 in fetal rat hepatocytes. Hepatology. 2001;33(4):860-7.

87. Colognato $H$, Yurchenco PD. Form and function: the laminin family of heterotrimers. Dev Dyn. 2000;218(2):213-34.

88. Koshikawa N, Moriyama K, Takamura H, Mizushima H, Nagashima Y, Yanoma $\mathrm{S}$, et al. Overexpression of laminin gamma2 chain monomer in invading gastric carcinoma cells. Cancer Res. 1999:59(21):5596-601.

89. Schenk S, Hintermann E, Bilban M, Koshikawa N, Hojilla C, Khokha R, et al. Binding to EGF receptor of a laminin-5 EGF-like fragment liberated during MMP-dependent mammary gland involution. J Cell biol. 2003;161(1):197-209.

90. Veitch DP, Nokelainen P, McGowan KA, Nguyen TT, Nguyen NE, Stephenson $\mathrm{R}$, et al. Mammalian tolloid metalloproteinase, and not matrix metalloprotease 2 or membrane type 1 metalloprotease, processes laminin5 in keratinocytes and skin. J Biol Chem. 2003;278(18):15661-8.

91. Wagstaff L, Kelwick R, Decock J, Edwards DR. The roles of ADAMTS metalloproteinases in tumorigenesis and metastasis. Front Biosci. 2011;16: 1861-72.

92. Nuttall RK, Sampieri CL, Pennington CJ, Gill SE, Schultz GA, Edwards DR. Expression analysis of the entire MMP and TIMP gene families during mouse tissue development. FEBS lett. 2004;563(1-3):129-34.

93. Crawford HC, Matrisian LM. Tumor and stromal expression of matrix metalloproteinases and their role in tumor progression. Invasion metastasis. 1994;14(1-6):234-45.

94. de Mingo M, Moran A, Sanchez-Pernaute A, Iniesta P, Diez-Valladares L, Perez-Aguirre E, et al. Expression of MMP-9 and TIMP-1 as prognostic markers in gastric carcinoma. Hepatogastroenterology. 2007;54(73):315-9.

95. Koontongkaew S. The tumor microenvironment contribution to development, growth, invasion and metastasis of head and neck squamous cell carcinomas. J Cancer. 2013;4(1):66-83.

96. Webber J, Yeung V, Clayton A. Extracellular vesicles as modulators of the cancer microenvironment. Semin Cell Dev Biol. 2015:40:27-34.

97. Cox TR, Gartland A, Erler JT. Lysyl oxidase, a targetable secreted molecule involved in Cancer metastasis. Cancer Res. 2016;76(2):188-92.

98. Erler JT, Bennewith KL, Cox TR, Lang G, Bird D, Koong A, et al. Hypoxiainduced lysyl oxidase is a critical mediator of bone marrow cell recruitment to form the premetastatic niche. Cancer Cell. 2009;15(1):35-44.

99. Gilkes DM, Bajpai S, Wong CC, Chaturvedi P, Hubbi ME, Wirtz D, et al. Procollagen lysyl hydroxylase 2 is essential for hypoxia-induced breast cancer metastasis. Mol Cancer Res. 2013;11(5):456-66.

100. Gerecke C, Scholtka B, Lowenstein Y, Fait I, Gottschalk U, Rogoll D, et al. Hypermethylation of ITGA4, TFPI2 and VIMENTIN promoters is increased in inflamed colon tissue: putative risk markers for colitis-associated cancer. J Cancer Res Clin Oncol. 2015;141(12):2097-107.

101. Dong Y, Tan Q, Tao L, Pan X, Pang L, Liang W, et al. Hypermethylation of TFPI2 correlates with cervical cancer incidence in the Uygur and Han populations of Xinjiang, China. Int J Clin Exp Pathol. 2015;8(2):1844-54

102. Kola I, Brookes S, Green AR, Garber R, Tymms M, Papas TS, et al. The Ets 1 transcription factor is widely expressed during murine embryo development and is associated with mesodermal cells involved in morphogenetic processes such as organ formation. Proc Natl Acad Sci U S A. 1993;90(16): 7588-92.

103. Nerlov C, De Cesare D, Pergola F, Caracciolo A, Blasi F, Johnsen M, et al. A regulatory element that mediates co-operation between a PEA3-AP-1 element and an AP-1 site is required for phorbol ester induction of urokinase enhancer activity in HepG2 hepatoma cells. EMBO J. 1992;11(12): 4573-82.

104. Vandenbunder B, Wernert N, Queva C, Desbiens X, Stehelin D. Does the transcription factor c-ets1 take part in the regulation of angiogenesis and tumor invasion? Folia Biol. 1994;40(5):301-13.

105. Carmeliet P. Angiogenesis in health and disease. Nat Med. 2003;9(6):653-60.

106. Mongiat M, Andreuzzi E, Tarticchio G, Paulitti A. Extracellular Matrix, a Hard Player in Angiogenesis. Int J Mol Sci. 2016;17(11)).

107. Rundhaug JE. Matrix metalloproteinases and angiogenesis. J Cell Mol Med. 2005;9(2):267-85.

108. Davidson B, Givant-Horwitz V, Lazarovici P, Risberg B, Nesland JM, Trope CG, et al. Matrix metalloproteinases (MMP), EMMPRIN (extracellular matrix metalloproteinase inducer) and mitogen-activated protein kinases (MAPK): co-expression in metastatic serous ovarian carcinoma. Clin Exp Metastasis. 2003;20(7):621-31

109. Gabison EE, Hoang-Xuan T, Mauviel A, Menashi S. EMMPRIN/CD147, an MMP modulator in cancer, development and tissue repair. Biochimie. 2005; 87(3-4):361-8

110. Lorenzon E, Colladel R, Andreuzzi E, Marastoni S, Todaro F, Schiappacassi M, et al. MULTIMERIN2 impairs tumor angiogenesis and growth by interfering with VEGF-ANEGFR2 pathway. Oncogene. 2012;31(26):3136-47.

111. Vreys V, David G. Mammalian heparanase: what is the message? J Cell Mol Med. 2007;11(3):427-52

112. Ibrahim SA, Hassan H, Vilardo L, Kumar SK, Kumar AV, Kelsch R, et al. Syndecan-1 (CD138) modulates triple-negative breast cancer stem cell properties via regulation of LRP-6 and IL-6-mediated STAT3 signaling. PloS one. 2013;8(12):e85737.

113. Ilan N, Elkin M, Vlodavsky I. Regulation, function and clinical significance of heparanase in cancer metastasis and angiogenesis. Int J Biochem Cell Biol. 2006;38(12):2018-39.

114. Sanderson RD, Yang Y, Suva LJ, Kelly T. Heparan sulfate proteoglycans and heparanase--partners in osteolytic tumor growth and metastasis. Matrix Bio. 2004;23(6):341-52.

115. Pyagay P, Heroult M, Wang Q, Lehnert W, Belden J, Liaw L, et al. Collagen triple helix repeat containing 1 , a novel secreted protein in injured and diseased arteries, inhibits collagen expression and promotes cell migration. Circ Res. 2005;96(2):261-8.

116. Yan Y, Wang LF, Wang RF. Role of cancer-associated fibroblasts in invasion and metastasis of gastric cancer. World J Gastroenterol. 2015; 21(33):9717-26.

117. Chen J, Tang D, Wang S, Li QG, Zhang JR, Li P, et al. High expressions of galectin-1 and VEGF are associated with poor prognosis in gastric cancer patients. Tumour Biol. 2014;35(3):2513-9.

118. Tang D, Gao J, Wang S, Ye N, Chong Y, Huang Y, et al. Cancer-associated fibroblasts promote angiogenesis in gastric cancer through galectin-1 expression. Tumour Biol. 2016;37(2):1889-99.

119. Gao Q, Yuan Y, Gan HZ, Peng Q. Resveratrol inhibits the hedgehog signaling pathway and epithelial-mesenchymal transition and suppresses gastric cancer invasion and metastasis. Oncol Lett. 2015;9(5):2381-7.

120. Katoh $Y$, Katoh M. Integrative genomic analyses on GLI1: positive regulation of GLI1 by hedgehog-GLI, TGFbeta-Smads, and RTK-PI3K-AKT signals, and negative regulation of GLI1 by notch-CSL-HES/HEY, and GPCR-Gs-PKA signals. Int J Oncol. 2009;35(1):187-92.

121. Sakaguchi M, Imaizumi Y, Shingo T, Tada H, Hayama K, Yamada O, et al. Regulation of adult neural progenitor cells by Galectin-1/beta1 integrin interaction. J Neurochem. 2010;113(6):1516-24.

122. Chong Y, Tang D, Xiong Q, Jiang X, Xu C, Huang Y, et al. Galectin-1 from cancer-associated fibroblasts induces epithelial-mesenchymal transition through beta1 integrin-mediated upregulation of Gli1 in gastric cancer. J Exp Clin Cancer Res. 2016;35(1):175.

123. Moiseeva EP, Williams B, Goodall AH, Samani NJ. Galectin-1 interacts with beta-1 subunit of integrin. Biochem Biophys Res Commun. 2003;310(3): 1010-6.

124. Chen H, Jia W, Li J. ECM1 promotes migration and invasion of hepatocellular carcinoma by inducing epithelial-mesenchymal transition. World J Surg Oncol. 2016;14(1):195.

125. Ye $X$, Tam WL, Shibue $T$, Kaygusuz $Y$, Reinhardt F, Ng Eaton E, et al. Distinct EMT programs control normal mammary stem cells and tumour-initiating cells. Nature. 2015;525(7568):256-60.

126. Lee KM, Nam K, Oh S, Lim J, Lee T, Shin I. ECM1 promotes the Warburg effect through EGF-mediated activation of PKM2. Cellular Signal. 2015;27(2): 228-35.

127. Achen MG, Stacker SA. Molecular control of lymphatic metastasis. Ann N Y Acad Sci. 2008;1131:225-34.

128. Zhuang $Z$, Jian $P$, Longjiang $L$, Bo $H$, Hongwei Z. Identification of oral cancer cell-induced changes in gene expression profile of lymphatic endothelial cell. Cancer Invest. 2008;26(10):1002-7.

129. Wu QW, She HQ, Liang J, Huang YF, Yang QM, Yang QL, et al. Expression and clinical significance of extracellular matrix protein 1 and vascular endothelial growth factor-C in lymphatic metastasis of human breast cancer. BMC Cancer. 2012;12:47.

130. Wang JP, Hu WM, Wang KS, Yu J, Luo BH, Wu C, et al. Expression of $\mathrm{C}-\mathrm{X}-\mathrm{C}$ chemokine receptor types $1 / 2$ in patients with gastric 
carcinoma: Clinicopathological correlations and significance. Oncol Lett. 2013:5(2):574-82.

131. Park SH, Das BB, Casagrande F, Tian Y, Nothnagel HJ, Chu M, et al. Structure of the chemokine receptor CXCR1 in phospholipid bilayers. Nature. 2012; 491(7426):779-83.

132. Saintigny P, Massarelli E, Lin S, Ahn YH, Chen Y, Goswami S, et al. CXCR2 expression in tumor cells is a poor prognostic factor and promotes invasion and metastasis in lung adenocarcinoma. Cancer Res. 2013;73(2):571-82.

133. Li Z, Wang Y, Dong S, Ge C, Xiao Y, Li R, et al. Association of CXCR1 and 2 expressions with gastric cancer metastasis in ex vivo and tumor cell invasion in vitro. Cytokine. 2014;69(1):6-13.

134. Loesch M, Zhi HY, Hou SW, Qi XM, Li RS, Basir Z, et al. p38gamma MAPK cooperates with c-Jun in trans-activating matrix metalloproteinase 9. J Biol Chem. 2010;285(20):15149-58.

135. Xu X, Jackson PL, Tanner S, Hardison MT, Abdul Roda M, Blalock JE, et al. A self-propagating matrix metalloprotease-9 (MMP-9) dependent cycle of chronic neutrophilic inflammation. PloS one. 2011;6(1):e15781.

136. Hazan RB, Qiao R, Keren R, Badano I, Suyama K. Cadherin switch in tumor progression. Ann N Y Acad Sci. 2004;1014:155-63.

137. van Roy F. Beyond E-cadherin: roles of other cadherin superfamily members in cancer. Nat Rev Cancer. 2014;14(2):121-34.

138. Zhao Y, Yang Y, Trovik J, Sun K, Zhou L, Jiang P, et al. A novel wnt regulatory axis in endometrioid endometrial cancer. Cancer Res. 2014;74(18): 5103-17.

139. Cereijido M, Valdes J, Shoshani L, Contreras RG. Role of tight junctions in establishing and maintaining cell polarity. Annu Rev Physiol. 1998;60:161-77.

140. Tsukita S, Furuse M. Pores in the wall: claudins constitute tight junction strands containing aqueous pores. J Cell Biology. 2000;149(1):13-6.

141. Balda MS, Garrett MD, Matter K. The ZO-1-associated Y-box factor ZONAB regulates epithelial cell proliferation and cell density. J Cell Biol. 2003;160(3):423-32.

142. Yamamoto Y, Nishimura N, Morimoto S, Kitamura H, Manabe S, Kanayama HO, et al. Distinct roles of Rab3B and Rab13 in the polarized transport of apical, basolateral, and tight junctional membrane proteins to the plasma membrane. Biochem Biophys Res Commun. 2003;308(2):270-5.

143. Plant PJ, Fawcett JP, Lin DC, Holdorf AD, Binns K, Kulkarni S, et al. A polarity complex of mPar-6 and atypical PKC binds, phosphorylates and regulates mammalian Lgl. Nat Cell Biol. 2003:5(4):301-8.

144. Yamanaka T, Horikoshi Y, Sugiyama Y, Ishiyama C, Suzuki A, Hirose T, et al. Mammalian Lgl forms a protein complex with PAR-6 and aPKC independently of PAR-3 to regulate epithelial cell polarity. Curr Biol. 2003; 13(9):734-43.

145. Pankov R, Yamada KM. Fibronectin at a glance. J Cell Sci. 2002;115(Pt 20): 3861-3.

146. Sottile J, Hocking DC. Fibronectin polymerization regulates the composition and stability of extracellular matrix fibrils and cell-matrix adhesions. Mol Biol Cell. 2002;13(10):3546-59.

147. Albiges-Rizo C, Destaing O, Fourcade B, Planus E, Block MR. Actin machinery and mechanosensitivity in invadopodia, podosomes and focal adhesions. J Cell Sci. 2009;122(Pt 17):3037-49.

148. Geiger B, Spatz JP, Bershadsky AD. Environmental sensing through focal adhesions. Nat Rev Mol Cell Biol. 2009;10(1):21-33.

149. Gao M, Craig D, Lequin O, Campbell ID, Vogel V, Schulten K. Structure and functional significance of mechanically unfolded fibronectin type III1 intermediates. Proc Natl Acad Sci U S A. 2003:100(25):14784-9.

150. Cao Y, Liu X, Lu W, Chen Y, Wu X, Li M, et al. Fibronectin promotes cell proliferation and invasion through MTOR signaling pathway activation in gallbladder cancer. Cancer Lett. 2015;360(2):141-50.

151. Park J, Schwarzbauer JE. Mammary epithelial cell interactions with fibronectin stimulate epithelial-mesenchymal transition. Oncogene. 2014 33(13):1649-57.

152. Balanis N, Wendt MK, Schiemann BJ, Wang Z, Schiemann WP, Carlin CR. Epithelial to mesenchymal transition promotes breast cancer progression via a fibronectin-dependent STAT3 signaling pathway. J Biol Chem. 2013; 288(25):17954-67.

153. Choy CT, Kim H, Lee JY, Williams DM, Palethorpe D, Fellows G, et al. Anosmin-1 contributes to brain tumor malignancy through integrin signal pathways. Endocr Relat Cancer. 2014;21(1):85-99.

154. Jian B, Nagineni CN, Meleth S, Grizzle W, Bland K, Chaudry I, et al. Anosmin1 involved in neuronal cell migration is hypoxia inducible and cancer regulated. Cell Cycle. 2009;8(22):3770-6.
155. Viana Lde S, Affonso RJ Jr, Silva SR, Denadai MV, Matos D. Salinas de Souza $C$, et al. relationship between the expression of the extracellular matrix genes SPARC, SPP1, FN1, ITGA5 and ITGAV and clinicopathological parameters of tumor progression and colorectal cancer dissemination. Oncology. 2013;84(2):81-91.

156. Hollier BG, Tinnirello AA, Werden SJ, Evans KW, Taube JH, Sarkar TR, et al. FOXC2 expression links epithelial-mesenchymal transition and stem cell properties in breast cancer. Cancer Res. 2013;73(6):1981-92

157. Kong B, Wang W, Esposito I, Friess H, Michalski CW, Kleeff J. Increased expression of Nodal correlates with reduced patient survival in pancreatic cancer. Pancreatology. 2015;15(2):156-61.

158. Hynes RO, Lander AD. Contact and adhesive specificities in the associations, migrations, and targeting of cells and axons. Cell. 1992;68(2):303-22.

159. Miranti CK, Brugge JS. Sensing the environment: a historical perspective on integrin signal transduction. Nat Cell Biol. 2002;4(4):E83-90.

160. Chan JL, Matarese G, Shetty GK, Raciti P, Kelesidis I, Aufiero D, et al. Differential regulation of metabolic, neuroendocrine, and immune function by leptin in humans. Proc Natl Acad Sci U S A. 2006;103(22):8481-6.

161. Wong CK, Cheung PF, Lam CW. Leptin-mediated cytokine release and migration of eosinophils: implications for immunopathophysiology of allergic inflammation. Eur J Immunol. 2007;37(8):2337-48.

162. Makrilia N, Kollias A, Manolopoulos L, Syrigos K. Cell adhesion molecules: role and clinical significance in cancer. Cancer Invest. 2009;27(10):1023-37.

163. Xiao X, Mruk DD, Cheng CY. Intercellular adhesion molecules (ICAMs) and spermatogenesis. Hum Reprod Update. 2013;19(2):167-86.

164. Jung CH, Lee WJ, Hwang JY, Seol SM, Kim YM, Lee YL, et al. The role of rho/ rho-kinase pathway in the expression of ICAM-1 by linoleic acid in human aortic endothelial cells. Inflammation. 2012;35(3):1041-8.

165. Tahtamouni LH, Shaw AE, Hasan MH, Yasin SR, Bamburg JR. Nonoverlapping activities of ADF and cofilin-1 during the migration of metastatic breast tumor cells. BMC Cell Biol. 2013;14:45.

166. Yeo TK, Nagy JA, Yeo KT, Dvorak HF, Toole BP. Increased hyaluronan at sites of attachment to mesentery by CD44-positive mouse ovarian and breast tumor cells. Am J Pathol. 1996;148(6):1733-40.

167. Brown-Augsburger P, Broekelmann T, Mecham L, Mercer R, Gibson MA, Cleary EG, et al. Microfibril-associated glycoprotein binds to the carboxylterminal domain of tropoelastin and is a substrate for transglutaminase. J Biol Chem. 1994;269(45):28443-9.

168. Finnis ML, Gibson MA. Microfibril-associated glycoprotein-1 (MAGP-1) binds to the pepsin-resistant domain of the alpha3(VI) chain of type VI collagen. J Biol Chem. 1997;272(36):22817-23.

169. Jia W, Li H, He YW. The extracellular matrix protein mindin serves as an integrin ligand and is critical for inflammatory cell recruitment. Blood. 2005; 106(12):3854-9.

170. Murphy-Ullrich JE, Sage EH. Revisiting the matricellular concept. Matrix Biol. 2014;37:1-14.

171. Bradshaw AD, Sage EH. SPARC, a matricellular protein that functions in cellular differentiation and tissue response to injury. J Clin Invest. 2001; 107(9):1049-54.

172. Podhajcer OL, Benedetti L, Girotti MR, Prada F, Salvatierra E, Llera AS. The role of the matricellular protein SPARC in the dynamic interaction between the tumor and the host. Cancer Metastasis Rev. 2008;27(3):523-37.

173. Mencalha AL, Levinsphul A, Deterling LC, Pizzatti L, Abdelhay E. SPARC-like1 mRNA is overexpressed in human uterine leiomyoma. Mol Med Rep. 2008; 1(4):571-4.

174. Adams JC, Lawler J. The thrombospondins. Cold Spring Harb Perspect Biol.. 2011;3(10):a009712.

175. Grose R, Dickson C. Fibroblast growth factor signaling in tumorigenesis. Cytokine Growth Factor Re. 2005;16(2):179-86.

176. Knights V, Cook SJ. De-regulated FGF receptors as therapeutic targets in cancer. Pharmacol Ther. 2010;125(1):105-17.

177. Baenziger NL, Brodie GN, Majerus PW. A thrombin-sensitive protein of human platelet membranes. Proc Natl Acad Sci U S A. 1971;68(1):240-3.

178. Jensen SA, Robertson IB, Handford PA. Dissecting the fibrillin microfibril: structural insights into organization and function. Structure. 2012;20(2):215-25.

179. Miyazono K, Olofsson A, Colosetti P, Heldin CH. A role of the latent TGFbeta 1-binding protein in the assembly and secretion of TGF-beta 1. EMBO J. 1991;10(5):1091-101.

180. Bao S, Ouyang G, Bai X, Huang Z, Ma C, Liu M, et al. Periostin potently promotes metastatic growth of colon cancer by augmenting cell survival via the Akt/PKB pathway. Cancer Cell. 2004;5(4):329-39. 
181. Baril P, Gangeswaran R, Mahon PC, Caulee K, Kocher HM, Harada T, et al. Periostin promotes invasiveness and resistance of pancreatic cancer cells to hypoxia-induced cell death: role of the beta4 integrin and the PI3K pathway. Oncogene. 2007;26(14):2082-94.

182. Zigrino P, Loffek S, Mauch C. Tumor-stroma interactions: their role in the control of tumor cell invasion. Biochimie. 2005;87(3-4):321-8.

183. Ricciardelli C, Sakko AJ, Ween MP, Russell DL, Horsfall DJ. The biological role and regulation of versican levels in cancer. Cancer Metastasis Rev. 2009; 28(1-2):233-45.

184. Du WW, Fang L, Yang X, Sheng W, Yang BL, Seth A, et al. The role of versican in modulating breast cancer cell self-renewal. Mol Cancer Res. 2013;11(5):443-55.

185. Lorenzo P, Aspberg A, Onnerfjord P, Bayliss MT, Neame PJ, Heinegard D. Identification and characterization of asporin. A novel member of the leucine-rich repeat protein family closely related to decorin and biglycan. J Biol Chem. 2001;276(15):12201-11.

186. Kalluri R, Zeisberg M. Fibroblasts in cancer. Nat Rev Cancer. 2006:6(5):392-401.

187. Jedeszko C, Victor BC, Podgorski I, Sloane BF. Fibroblast hepatocyte growth factor promotes invasion of human mammary ductal carcinoma in situ. Cancer Res. 2009;69(23):9148-55.

188. Bouchard V, Demers MJ, Thibodeau S, Laquerre V, Fujita N, Tsuruo T, et al. Fak/Src signaling in human intestinal epithelial cell survival and anoikis: differentiation state-specific uncoupling with the PI3-K/Akt-1 and MEK/Erk pathways. J Cell Physiol. 2007:212(3):717-28.

189. Bouchard V, Harnois C, Demers MJ, Thibodeau S, Laquerre V, Gauthier $\mathrm{R}$, et al. B1 integrin/Fak/Src signaling in intestinal epithelial crypt cell survival: integration of complex regulatory mechanisms. Apoptosis. 2008;13(4):531-42.

190. Gendler SJ, Spicer AP. Epithelial mucin genes. Annu Rev Physiol. 1995;57: 607-34.

191. Lee HS, Lee HK, Kim HS, Yang HK, Kim Yl, Kim WH. MUC1, MUC2, MUC5AC, and MUC6 expressions in gastric carcinomas: their roles as prognostic indicators. Cancer. 2001;92(6):1427-34.

192. Pinto-de-Sousa J, David L, Reis CA, Gomes R, Silva L, Pimenta A. Mucins MUC1, MUC2, MUC5AC and MUC6 expression in the evaluation of differentiation and clinico-biological behaviour of gastric carcinoma. Virchows Arch. 2002:440(3):304-10.

193. Chen S, Fukuda M. Cell type-specific roles of carbohydrates in tumor metastasis. Methods Enzymol. 2006;416:371-80.

194. Miyagi T, Wada T, Yamaguchi K, Hata K. Sialidase and malignancy: a minireview. Glycoconj J. 2004;20(3):189-98.

195. Wang FL, Cui SX, Sun LP, Qu XJ, Xie YY, Zhou L, et al. High expression of alpha 2, 3-linked sialic acid residues is associated with the metastatic potential of human gastric cancer. Cancer Detect Prev. 2009;32(5-6):437-43.

\section{Publisher's Note}

Springer Nature remains neutral with regard to jurisdictional claims in published maps and institutional affiliations.

Ready to submit your research? Choose BMC and benefit from:

- fast, convenient online submission

- thorough peer review by experienced researchers in your field

- rapid publication on acceptance

- support for research data, including large and complex data types

- gold Open Access which fosters wider collaboration and increased citations

- maximum visibility for your research: over $100 \mathrm{M}$ website views per year

At $\mathrm{BMC}$, research is always in progress.

Learn more biomedcentral.com/submissions 